\section{FEDERAL WIRE ACT SHOULD ADJUST TO STATE-REGULATED SPORTS WAGERING, NOT THE OTHER WAY AROUND: A PROPOSAL FOR CHANGE}

\section{ANTHONY CABOT AND GREG CLOWARD}

Anthony Cabot is a distinguished fellow in gaming law at the William S. Boyd School of Law at the University of Nevada, Las Vegas (UNLV), in Las Vegas, Nevada, USA.

Greg Cloward is a graduate of the Harrah College of Hospitality at UNLV and a law student at UNLV's Boyd School of Law in las Vegas, Nevada, USA.

\section{INTRODUCTION}

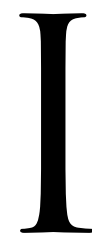
n 1961, Congress enacted the Federal Wire Act ("Wire Act"), ${ }^{1}$ which criminalized the use of interstate telephone lines to operate a betting or wagering business. ${ }^{2}$ The Wire Act resulted from an effort by the federal government in 1961 to suppress local criminal activities that supported national criminal organizations. ${ }^{3}$ Accord- ing to then-U.S. Attorney General Robert Kennedy, the target was organized crime. ${ }^{4}$ The Wire Act was consistent with the prevalent intent of Congress's primary goal in adopting federal gambling crimes. While the wording of the Wire Act is a grammarian's nightmare, ${ }^{5}$ it sought to assist states in protecting their legal gambling markets, a salutary objective, rather than undermining legal markets they created. The imprecision of the drafters, however, opened the door for interpretations inconsistent with the original legislative intent. The Wire Act, however, is no longer being used as the tool envisioned by Congress in 1961. Instead, some land-based casino operators and religious proponents have used it as an anticompetitive weapon to create a federal prohibition against online gaming activities. Unfortunately, for the past 20 years, the meaning of the Wire Act has been a political football in the United States Department of Justice (DOJ). ${ }^{6}$

An easy solution, of course, is for Congress to clarify and modernize federal gambling laws. But, the federal government is not engaging in thoughtful policymaking designed to make federal law consistent with modern technologies, prevalent state policies, laws and attitudes toward regulated gambling, and the diminution of organized crime in regulated gaming markets. Instead, the Trump administration bowed to political considerations to try to force an interpretation of the Wire Act that in no way comports with sounded public policy. ${ }^{7}$ Thus, this strange saga of attempting to engage in rulemaking within a biased Department of Justice has forced the issue into courtrooms as opposed to the halls of Congress.
Keywords: internet gambling, Federal Wire Act, public policy, sports wagering, public policy

DOI: 10.1089/glr2.2021.0004 (c) 2021 Mary Ann Liebert, Inc.

${ }^{1}$ See generally, Anthony N. Cabot, Federal Gambling Law 115-24 (1999); David G. Schwartz, Not Undertaking the Almost-Impossible Task: The 1961 Wire Act's Development, Initial Applications, and Ultimate Purpose, 14 Gaming L. Rev. 533 (2010).

${ }^{2}$ CABot, supra note 1 , at $115 ; 18$ U.S.C. $\S 1084$

${ }^{3}$ CАBOT, supra note 1; Schwartz, supra note 1.

${ }^{4}$ Jordan Hollander, The House Always Wins: The World Trade Organization, Online Gambling, and State Sovereignty, 18 Gaming L. Rev. \& Econ. 461, 464 (2014).

${ }^{5}$ Anthony Cabot, The Absence of a Comprehensive Federal Policy Toward Internet and Sports Wagering and a Proposal for Change, 17 ViLL. SPORTS \& ENT. L.J. 271, 282 (2010) ("The Wire Act, in its entirety, reads poorly and in parts, the Act is nearly incomprehensible."); Byron La Fleur, Why Commas Matter: The Wire Act Story, LA FLEUR's, https://lafleurs.com/magazine-feature/feature-magazine-feature/ 2019/02/13/why-commas-matter/ (last accessed Apr. 21, 2020) (discussing how the use of commas and poor grammar have led to all of the uncertainty surrounding the Wire Act).

${ }^{6}$ The interpretation of the Wire Act has changed with different administrations. The Bush administration interpreted the Wire Act as applying to and outlawing all internet gambling. Michelle Minton, The Original Intent of the Wire Act and Its Implications for State-Based Legalization of Internet Gambling, UNLV CENTER Gaming Res., Sept. 2014, at 6, at https://digitalscholarship.unlv.edu/cgi/ viewcontent.cgi? article $=1035 \&$ context $=$ occ_papers. The Obama administration then changed course in 2011 and declared the Wire Act applied only to sports betting. Office of Legal Counsel, Whether Proposals by Illinois and New York to Use the Internet and Out-of-State Transaction Processors to Sell Lottery Tickets to in-State Adults Violate the Wire Act (Sept. 20, 2011). And now, the Trump administration has flipped that understanding and said the Wire Act applies to all forms of internet gambling. Office of Legal Counsel, Reconsidering Whether the Wire Act Applies to Non-Sports Gambling (Nov. 2, 2018). Whether this new interpretation will lead to Department of Justice (DOJ) enforcement is yet to be seen.

${ }^{7}$ Peter J. Ferrara, Department of Justice Shouldn't End Online Gambling to Appease Trump Donor Sheldon Adelson, USA TodAY (Feb. 7, 2019), https://www.usatoday. com/story/opinion/2019/02/07/justice-department-online-gambling-gop-donorsheldon-adelson-trump-column/2787194002/. 
The latest flare-up in the sordid history of the Wire Act came on January 14, 2019. The U.S. Department of Justice, in a rebuke of its previous position, released an opinion insinuating that the 60 -year-old statute prohibited all forms of state-authorized internet and interactive wagering, including sports, state lotteries, poker, and casino games. ${ }^{8}$ This could have a significant impact on gaming revenues in the many states with a regulated sports wagering industry, in states that sell state lottery tickets online, and a host of other states with authorized online casino games. A federal district court in New Hampshire settled the waters when it set aside the DOJ opinion. ${ }^{9}$ In January 2021, the First Circuit agreed with the district court and concluded "the prohibitions of section 1084 (a) apply only to the interstate transmission of wire communications related to any 'sporting event or contest." "10

Regardless of the outcome of this latest case, the better question is to ask why doesn't the Congress undertake a review and potential repeal or revision of the Wire Act? This could return the federal government to its avowed policy of assisting the states in the enforcement of state law respectful of the individual state policies toward illegal and regulated gaming.

Over a third of the states have authorized mobile and online sports wagering as the result of the United States Supreme Court case striking the Professional and Amateur Sports Protection Act (PASPA), ${ }^{11}$ which practically restricted sports wagering to Nevada. Since that decision, several states have authorized sports betting in one of the most rapid expansions of a form of gambling in U.S. history. ${ }^{12}$ Other states are considering legislation that would permit sports betting, and the number of states legalizing and regulating sports betting will inevitably increase in the coming few years. ${ }^{13}$

The Federal Wire Act requires revision to meet goals to assist these states in protecting their regulated sports industries, the state's tax interest in the industry, or the integrity of the underlying games. Nor has the government used the Wire Act as a tool against illegal sports wagering businesses. The Wire Act has only been the subject of a small number of reported cases over the past decade. ${ }^{14}$ At the same time, the size of the illegal sports gambling markets is enormous. ${ }^{15}$ Instead, the Wire Act remains controversial because it offers a means for private land-based casino interests to limit competition from mobile and internet sites by influencing rulemaking at the United States Department of Justice. ${ }^{16}$

This article reviews the history and policies behind the Wire Act, the recent controversies surrounding the Wire Act, and how state policies toward gambling have shifted. All of these factors lead to a proposal for amending the Federal Wire Act that restores the fundamental federal policy goal of aiding the states in more effectively enforcing their gaming protections and regulating their permitted gaming industries, protecting Americans from illegal operators, and cutting off the flow of money to illicit operators and their organized crime connections.

\footnotetext{
${ }^{8}$ Anthony Cabot, Murky Motivations, IGAming Business (Dec. 6, 2019), https:// www.igbnorthamerica.com/murky-motivations/.

${ }^{9}$ New Hampshire Lottery Comm'n (NHLC) v. Barr, 386 F. Supp. 3d 132, 153 (D.N H. 2019).

${ }^{10}$ New Hampshire Lottery Commission v. Jeffrey Rosen, No. 19-1835 (1st Cir. Jan. 20, 2021) (Rosen replaced Barr as the attorney general).

${ }^{11}$ See infra note 183 and accompying text.

${ }^{12}$ As of May 1, 2020, the following states have legalized sports betting and that activity is being conducted in the state: Arkansas, Colorado, Delaware, Illinois, Indiana, Iowa, Nevada, New Hampshire, New Jersey, New York, Michigan, Mississippi, Montana, Oregon, Pennsylvania, Rhode Island, and West Virginia. Legislative Tracker: Sports Betting, LEGAL SpoRTs ReP., https://www legalsportsreport.com/sportsbetting-bill-tracker/ (last updated Apr. 7, 2020). New Mexico also offers sports betting at some of its tribal casinos through a gaming compact. Id.
}

\footnotetext{
${ }^{13}$ As of May 1, 2020, North Carolina, and Tennessee have legalized sports betting and are pending launch. Id. Alabama, Alaska, Arizona, California, Connecticut, Florida, Georgia, Hawaii, Kansas, Kentucky, Louisiana, Maine, Maryland, Massachusetts, Minnesota, Missouri, Nebraska, North Dakota, Ohio, South Carolina, South Dakota, Texas, Vermont, Virginia, Washington, and Wyoming have all at least introduced bills that would legalize sports betting. See id

${ }^{14}$ U.S. v. Seng Chen Yong, 926 F.3d 582 (9th Cir. 2019), United States v. Merlino, No. 18-3272-cr (2d Cir. Nov. 7, 2019), United States v. Duplantis, No. 1: 19 CR116 (E.D. Tex. Sept. 6, 2019).

${ }^{15}$ Jordan Weissmann, Big Bucks of Bogus Betting Baloney?, SLATE (Nov. 21, 2014), https://slate.com/business/2014/11/adam-silver-says-theres-400-billion-per-yearof-illegal-sports-betting-in-the-u-s-alone-seriously.html

${ }^{16}$ See questioning by Judge William Kayatta Jr. in the Professional and Amateur Sports Protection Act (PASPA) case in the Third Ciricuit. Jennifer Newell, US Court of Appeals Hears Wire Act Oral Arguments, LeGAL US POKER Sites (June 18, 2020), https://www.legaluspokersites.com/news/us-court-of-appeals-arguments/ 21547/.
} 


\section{AN HISTORICAL PERSEPECTIVE}

\section{A. Before the Wire Act and after}

From the time of his appointment as attorney general of the United States, Robert F. Kennedy had sought federal legislation to aid the states in furthering his goal of eliminating interstate rackets. ${ }^{17}$ Kennedy focused on bookmaking and the necessity of wire communications to facilitate organized crime's gambling operations. ${ }^{18}$ By advocating for a federal prohibition on interstate bet transmissions, the Wire Act would give law enforcement a means by which to stop out-of-state bookies from wiring information related to betting and gambling into their jurisdictions. ${ }^{19}$

For Kennedy, the Wire Act was less about betting on horses or sporting events and more about targeting organized crime, the dominant purveyors of gambling. ${ }^{20}$ Throughout the legislative process, Kennedy's campaign against organized crime overshadowed any concern for the casual bettor's access to a book. ${ }^{21}$ Indeed, the Act expressly excludes the casual gambler from criminal liability by targeting only persons "engaged in the business of betting or wagering." 22 The gambling activities themselves were not the problem, except to the extent that they provided a vehicle for a crime. ${ }^{23}$

The Wire Act did not include wireless communications and covered only activities that fell under the reasonability of the Federal Communications Commission. ${ }^{24}$ Kennedy assured the telecommunications lobby that companies would not be liable for providing services used for illegal gambling activities, pro- vided they did not intentionally enable the crimes. ${ }^{25}$ Coupled with his assurances that the purpose of the Act was not to police betting "between acquaintances, ${ }^{26}$ the legislation never intended selective implementation by law enforcement. ${ }^{27}$ "True offenders" would be targeted, leaving the rest of the $\$ 7$ billion (at the time) ${ }^{28}$ gambling industry unencumbered. ${ }^{29}$

On September 13, 1961, John F. Kennedy signed the Wire Act into law alongside the Travel Act and the Wagering Paraphernalia Act. ${ }^{30}$ The following year, Congress renewed its investigation of organized crime and interstate sports gambling. ${ }^{31}$ The reporting subcommittee recommended amending the Wire Act to account for technological advancements in telecommunications. ${ }^{32}$ While the issue was never taken up, that the Wire Act was initially limited in scope indicates the narrow focus intended by its authors. ${ }^{33}$ This questions whether the Act can be used to police technologies not prevalent, or in the case of the internet, not even imagined, at the time of passing. ${ }^{34}$

\section{B. The Wire Act}

The Wire Act's prohibition section reads:

Whoever being engaged in the business of betting or wagering knowingly uses a wire communication facility for the transmission in interstate or foreign commerce of bets or wagers or information assisting in the placing of bets or wagers on any sporting event or contest, or for the transmission of a wire communication which entitles the recipient to receive money or credit as a result

\footnotetext{
${ }^{17}$ Schwartz, supra note 1, at 533-34; H.R. ReP. No. 87-966 ("Over the years an ever-increasing portion of our national resources has been diverted into illicit channels. Because many rackets are conducted by highly organized syndicates whose influence extends over State and National borders, the Federal Government should come to the aid of local law enforcement in an effort to stem such activity.").

${ }^{18}$ Schwartz, supra note 1, 534-35; The Attorney General's Program to Curb Organized Crime and Racketeering: Hearings on S. 1653, S. 1654, S. 1655, S. 1656 , S. 1657 , S. 1658 , S. 1665 Before the S. Comm. on the Judiciary, 87 th Cong. at 6 (1961) ("It is quite evident that modern, organized, commercial gambling operations are so completely intertwined with the Nation's communications systems that denial of their use to the gambling fraternity would be a mortal blow to their operations.").

${ }^{19}$ Schwartz, supra note 1 , at 535 .

${ }^{20} I d$. at 533 .

${ }^{21} I d$. at 535

${ }^{22}$ CABOT, supra note 1 , at 123 ; $11084(\mathrm{a})$.

${ }^{23}$ Schwartz, supra note 1 , at 535 .
}

${ }^{24} I d$. at 536

${ }^{25} I d$.

${ }^{26}$ Attorney General's Program to Curb Organized Crime and Racketeering, supra note 18 , at $12-13$.

${ }^{27}$ Scwartz, supra note 1 , at 536

${ }^{28} I d$. at 535 .

${ }^{29} I d$. at 536.

${ }^{30} I d$. at 537.

${ }^{31} I d$.

${ }^{32} I d$. at 538 .

${ }^{33} I d$.

${ }^{34} I d$. 
of bets or wagers, or for information assisting in the placing of bets or wagers, shall be fined under this title or imprisoned not more than two years, or both. $^{35}$

A crime under the Wire Act thus consists of three elements: (1) persons engaged in the business of betting or wagering; (2) use of a wire communication facility; and (3) the transmission of wagering on sporting events or horse racing. ${ }^{36}$

To be considered a person "engaged in the business of betting or wagering," courts generally require that a party be engaged in both the "sale of a product or service for a fee" 37 and a "continuing course of conduct." 38 The Wire Act thus targets gambling operators who charge customers for services related to accepting or brokering wagers. ${ }^{39}$ While "bookies" were clearly covered, prosecutors tested the scope of the Wire Act immediately. In 1964, the government conducted a sting by which it caught 27 tipsters involved in the multi-million-dollar business of advising clients on which wagers to make. ${ }^{40}$ Because the touts used telephone lines to transmit their gambling information, federal prosecutors found them to be within the purview of the Act. ${ }^{41}$ In 1998, the Justice Department used the Wire Act to crack down on online betting sites based overseas. ${ }^{42}$ Of those charged, ten people pled guilty to conspiring to violate the Wire Act, while seven elected to remain abroad to avoid prosecution. ${ }^{43}$ As previously noted, the Act's language, however, was purposefully narrow to target professional bookmakers and their service providers while leaving the "casual" gambler free to participate in games (via telephone, or now, over the internet) without fear of prosecution. ${ }^{44}$
The Wire Act's language regarding "wire communications [facilities]" refers to systems used to transmit writings, pictures, or sound "by and of a wire, cable or other like connection between points of origin and reception of such transmission." 45 At the time of the Act's enactment, this included telecommunications and ticker machines, which printed information on paper tape. ${ }^{46}$ Not contemplated at the time was the internet, which resulted in widespread personal computer and mobile phone use. ${ }^{47}$ Nevertheless, the Act applies to most online communications because most communications use cable at some point in the transmission, whether it be telephone or fiber cable. ${ }^{48}$

At the time of its enactment, using a phone line for gambling activities other than wagering on sports was unrealistic and so the Act presumably prohibited only wagering on sporting events or contests. ${ }^{49}$ The legislative history and application of the statute in court broadly supports this conclusion. ${ }^{50}$ As discussed in the next section, the poor drafting of the Wire Act opened an opportunity to argue an expanded scope that the Wire Act applies to non-sports.

The Wire Act's "knowingly" mens rea ${ }^{51}$ requirement does not require that a defendant know that he was violating the Act, only that he was aware of the underlying illegal conduct was occurring. ${ }^{52}$ In United States v. Cohen, the defendant was convicted under the Wire Act for operating a sports wagering website called the World Sports Exchange. ${ }^{53}$ On appeal, the Second Circuit affirmed the lower court's finding that Cohen need only know "that the deeds described in the statute as being prohibited were being done"

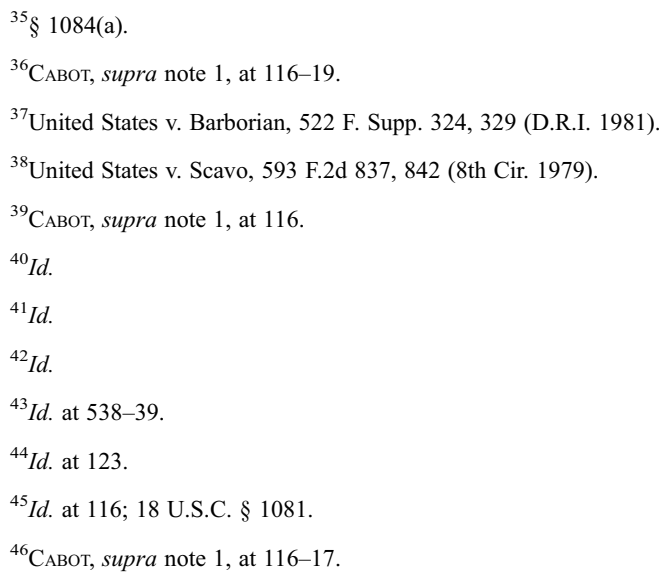

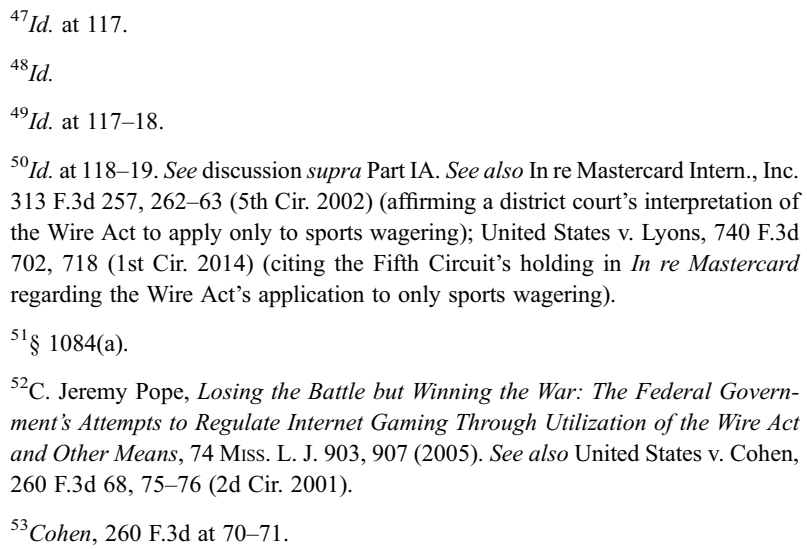


to violate the Act. ${ }^{54}$ Neither misinterpretation nor ignorance of the law was a valid excuse for Cohen's conduct. $^{55}$

The Act contains two safe harbors: the first for the transmission of information for use in news reporting, and the second for the transmission of information assisting in the placing of bets or wagers from a jurisdiction where sports wagering is legal to another jurisdiction where sports wagering is legal. ${ }^{56}$ Of note, while the Act's safe harbor provision protects the transmission of sports wagering information between two jurisdictions which permit sports betting, it does not protect the transmission of actual bets or wagers. ${ }^{57}$ Penalties for violations of the Wire Act can include up to two years in federal prison and a fine. ${ }^{58}$

\section{RECENT WIRE ACT CONTROVERSIES}

Overstating to what extent the gaming industry has changed since the passage of the Wire Act is difficult. In 1961, Nevada was the only state with legal casino gambling, sports wagering, and off-track betting on horse racing. ${ }^{59}$ Tribal gaming was nonexistent, and New Hampshire would not became the first state to operate a lottery in the modern era for another three years. ${ }^{60}$ Today, commercial casinos (non-tribal) operate in 26 states. ${ }^{61}$ Forty-five states and the District of Columbia operate state lotteries, and tribal gaming exists in 29 states. $^{62}$ In 2019 , the gaming industry earned $\$ 43.6$ billion in revenue. ${ }^{63}$
Unsurprisingly, the telecommunications industry has experienced significant change over the past half-century. Through a combination of "clever marketing, mergers, and strategic deals with the government," AT\&T operated as a telecommunications monopoly from 1932 to $1982 .{ }^{64}$ In January 1982 , after fighting an antitrust suit for six years, AT\&T made a deal with the DOJ to break up its monopoly, creating a competitive telecommunications industry for the first time in 50 years. ${ }^{65}$ Inconceivable in 1961 was the advent of mobile phones and but, by 2018, 55 percent of American households had only wireless telephones. ${ }^{66}$ That number jumped to 75 percent for ages $25-34 .^{67}$

\section{A. 2011 DOJ Wire Act opinion}

In December 2009, officials from New York and Illinois wrote letters to the DOJ seeking an opinion on the states' plans to sell lottery tickets within their states via the internet using out-of-state transaction processors. ${ }^{68}$ New York was ready to implement a new computerized system by which virtual lottery tickets would be delivered to customers over the internet to computers or mobile phones. ${ }^{69}$ Transaction data would be routed from the customer's device in New York to the lottery's data centers in either New York or Texas moving through networks controlled in Maryland and Nevada. ${ }^{70}$ Illinois also planned to sell lottery tickets online with geofencing used to ensure that the buyer was physically present within the state. ${ }^{71}$ Illinois characterized its system as intra-state despite that some transaction data may be routed

\footnotetext{
${ }^{54} I d$. at $75-76$.

${ }^{55} I d$.

${ }^{56} \S 1084$ (b) ("Nothing in this section shall be construed to prevent the transmission in interstate or foreign commerce of information for use in news reporting of sporting events or contests, or for the transmission of information assisting in the placing of bets or wagers on a sporting event or contest from a State or foreign country where betting on that sporting event or contest is legal into a State or foreign country in which such betting is legal.").

${ }^{57} I d$.

${ }^{58} \mathrm{CABOT}$, supra note 1 , at 123

${ }^{59}$ See generally David G. Schwartz, Roll the Bones: The History of Gambling 391-446 (2006).

${ }^{60} I d$. at $386-90,433-39$.

${ }^{61}$ American Gaming Association, State of the States 2020: The AGA Survey of the Commercial Casino Industry (2019), at 12-13, https://www.americangaming.org/ resources/state-of-the-states-2020/.

${ }^{62} I d$.
}

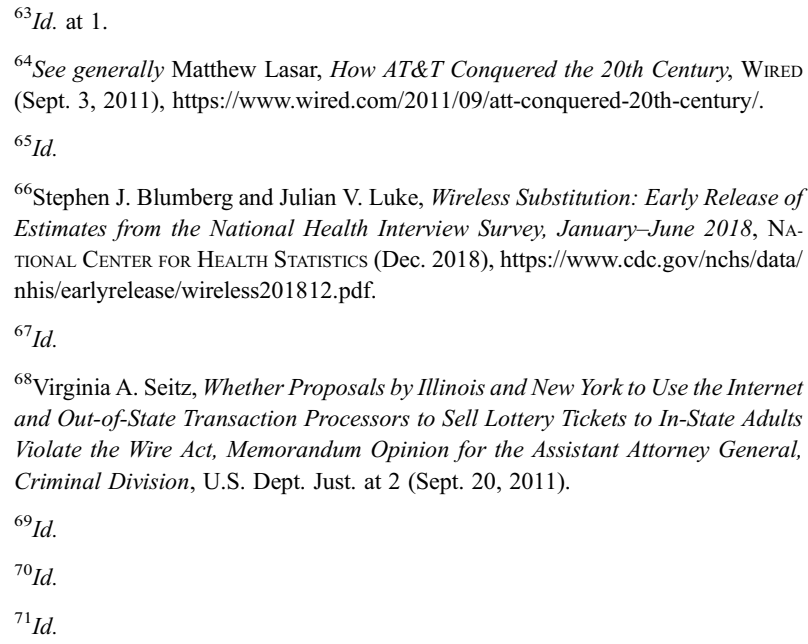
Estimates from the National Health Interview Survey, January-June 2018, NAtional Center for Health Statistics (Dec. 2018), https://www.cdc.gov/nchs/data/ nhis/earlyrelease/wireless201812.pdf.

${ }^{67} I d$.

${ }^{68}$ Virginia A. Seitz, Whether Proposals by Illinois and New York to Use the Internet and Out-of-State Transaction Processors to Sell Lottery Tickets to In-State Adults Violate the Wire Act, Memorandum Opinion for the Assistant Attorney General, Criminal Division, U.S. Dept. Just. at 2 (Sept. 20, 2011).

${ }^{69} I d$.

${ }^{70} I d$.

${ }^{71} I d$. 
across state lines over the internet. ${ }^{72}$ Both states argued that their proposals did not implicate the Wire Act because neither plan involved the communication of information related to sports wagering across state lines. ${ }^{73}$

Over a year and a half later, the DOJ had yet to respond to the two states' inquiries. ${ }^{74}$ In July 2011, concerned over recent indictments of online poker operators in New York and Baltimore, Senators Harry Reid and Jon Kyl sent a joint letter to Attorney General Eric Holder requesting that the DOJ state its opinion on the legality of internet gambling. ${ }^{75}$ The letter blamed a years-long lack of activity by law enforcement for the growing perception that either internet gambling was not against U.S. law or that the DOJ "thought that the case was uncertain enough that it chose not to pursue enforcement efforts." 76 It also referred to "several officials from various state lotteries" who were convinced that they had obtained the DOJ's "effective consent" to implement internet gambling because the DOJ had not objected to their proposals "despite many months or years." 77 Senators Reid and Kyl urged the DOJ to "pursue aggressively and consistently" those offering "illegal" internet gambling in the U.S. ${ }^{78}$

Shortly after that, the DOJ did release a response to the states of New York and Illinois. ${ }^{79}$ It was neither the response which the Senators expected nor the one for which they likely hoped. ${ }^{80}$ Far from reaffirming its "longstanding"-per the Senatorsposition that all forms of internet gambling were illegal, the DOJ concluded that the Wire Act applied only to "sports-related gambling activities." ${ }^{81}$ Noting that the text of the Act could "be read either way," the DOJ reached its conclusion mainly by investigating the Act's legislative history. ${ }^{82}$

Section 1084(a) contains two main clauses: (1) the prohibition on using a wire communications facility to "for the transmission in interstate or foreign commerce of bets or wagers or information assisting in the placing of bets or wagers on any sporting event or contest;" and (2) the prohibition of wire communications "which entitle[] the recipient to receive money or credit as a result of bets or wagers, or for information assisting in the placing of bets or wagers." 83 The DOJ thus set out to determine whether the language "on any sporting event or contest" was meant to modify each instance of "bets or wagers" found in section 1084(a), or only the instance immediately preceding the language. ${ }^{84}$ The DOJ determined that it would be "the more logical result" if the "on any sporting event or contest" language was applied to each instance of "bets or wagers." "85 While straining logic, Congress could have prohibited all bets or wagers, but only information assisting in bets or wagers on sporting events. The DOJ found no discernable reason for Congress to do so. ${ }^{86}$

The Wire Act's legislative history supports the DOJ's conclusion. The language originally proposed for section 1084(a) would impose criminal liability on anyone using a wire communications facility "for the transmission in interstate or foreign commerce of bets or wagers, or information assisting in the placing of bets or wagers, on any sporting event or contest . . " "87 The commas around "or information assisting in the placing of bets or wagers"-which for some reason did not make it into the Act's final language - made it clear that "on any sporting event or contest" was meant to modify both phrases. ${ }^{88}$

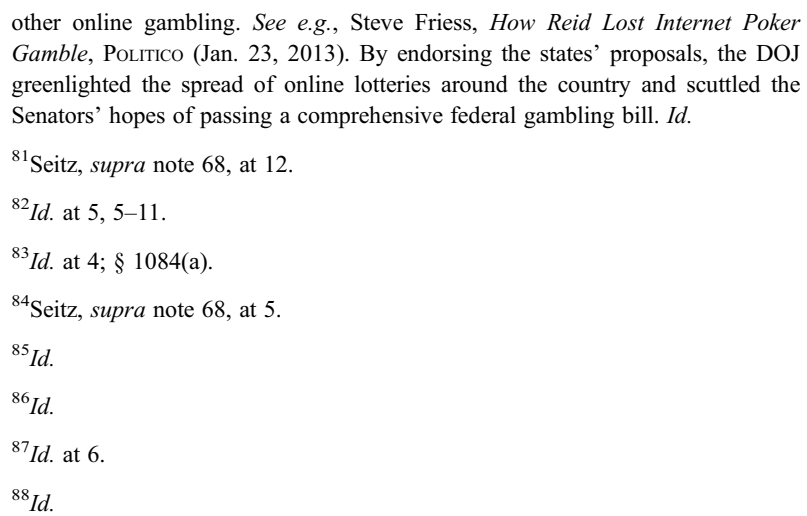

${ }^{80}$ There is much speculation that Reid-Kyl letter was sent to lay the groundwork for a bill which would legalize online poker, but which would prohibit virtually all 
Additionally, the DOJ found nothing in the congressional or Senate hearings before the passing of the Act that would suggest that its aim was anything other than sports wagering. ${ }^{89}$ Following the DOJ's 2011 interpretation of the Wire Act, many states began using out-of-state servers to back up data, and online gambling expanded across the nation. ${ }^{90}$

\section{B. 2018 DOJ Wire Act opinion}

In November 2018, the DOJ reversed its interpretation of the Wire Act and concluded that "on any sporting event or contest" modified only the prohibition on transmitting "information assisting in the placing of bets or wagers" and none of section 1084 (a)'s other clauses. ${ }^{91}$ The opinion found the plain language of section 1084 to be unambiguous, conveniently eliminating any need for the DOJ to "delve" into the congressional record of the act "even if so inclined." 92 The opinion arrives at its conclusion of unambiguity after a lengthy grammatical analysis comparing the "last-antecedent rule" with the "series-qualifier rule." 93 The ultimate conclusion was that "the linguistic maneuvers that are necessary to conclude that the sports-gambling modifier sweeps both backward and forward to reach all four of section 1084(a)'s prohibitions are too much for the statutory text to bear."
Having concluded that the Wire Act implicated all forms of internet gambling and is not only limited to sports wagering, the opinion then turns to the interaction between the Wire Act and the Unlawful Internet Gambling Enforcement Act (UIGEA). ${ }^{95}$ The DOJ concluded that even though UIGEA's definition of "unlawful Internet gambling" excluded certain activities, it had no impact on other federal gambling statutes. ${ }^{96}$ Because the 1961 Wire Act has no definition of "unlawful Internet gambling" and because the UIGEA expressly does not "alter, limit, or extend" any other federal, state, or tribal law, the opinion concludes, the UIGEA "simply does not affect what activities are lawful under the Wire Act." 97 The new opinion caused general confusion throughout the gaming industry and quickly the subject of a federal court action in New Hampshire. ${ }^{98}$

\section{New Hampshire Lottery} Commission v. Barr

The New Hampshire Lottery Commission (NHLC) and its iLottery vendor, NeoPollard Interactive (NeoPollard), sued the Department of Justice for declaratory relief, ${ }^{99}$ fearing that the 2018 DOJ opinion would criminalize lottery games upon which the state relies for revenue. ${ }^{100}$ NHLC was joined in amici by New Jersey, Pennsylvania, and the Michigan Bureau of State Lottery. ${ }^{101}$ Both parties moved for summary
${ }^{89} I d$. at $6-10$. Robert Kennedy had testified that the people affected by the Act would be "the bookmakers and the layoff men, who need incoming and outgoing wire communications in order to operate." Id. at 9

${ }^{90}$ See generally Mark Hichar and Erica Okerberg, New Hampshire Lottery Strikes Back: The U.S. District Court Holds That the Wire Act Applies Only to Sports Betting, 23(8) Gaming L. Rev. 594 (2019); Richard N. Velotta, Justice Department's Wire Act Interpretation Continues to Confuse, LAS VeGas ReVIEW-JournaL (Oct. 14, 2019), https://www.reviewjournal.com/business/casinos-gaming/justice-departmentswire-act-interpretation-continues-to-confuse-1870735/.

${ }^{91}$ See Steven A. Engel, Reconsidering Whether the Wire Act Applies to Non-Sports Gambling, U.S. Dept. Just. (Nov. 2, 2018).

${ }^{92} I d$. at $16-17$. The opinion also dismisses the 2011 opinion's concern that Congress would have no discernible reason for only limiting "information assisting" to sports-related gambling instead noting that, while improbable that Congress would make such a decision, "improbable is not absurd, and [. . . ] anomaly largely falls away if, as we have concluded, transmitting bets or wagers of any kind is indeed unlawful under section 1084(a)'s first clause." Id. at 15.

${ }^{93} I d$. at $7-10$. The "last-antecedent rule" is characterized generally as "a limiting clause or phrase ... should ordinarily be read as modifying only the noun or phrase that it immediately follows." Id. at 7 (internal citations omitted). The "seriesqualifier rule" provides that "a modifying phrase used to qualify one element of a list of nouns or verbs may sweep beyond the nearest referent if the list 'contain[s] items that readers are used to seeing listed together or a concluding modifier that readers are accustomed to applying to each of them." Id. at 8-9.

\footnotetext{
${ }^{94} I d$. at $13-14$ (internal citations omitted).

${ }^{95} I d$. at $17-18$. See also 31 U.S.C. $\S \S 5361-67$. The 2011 opinion did not address the Unlawful Internet Gambling Enforcement Act (UIGEA) after it concluded that the Wire Act applies only to sports wagering. Seitz, supra note 68, at 13.

${ }^{96}$ Engel, supra note 80 , at 18 . The UIGEg
}

A, for example, excludes bets or wagers "initiated and received or otherwise made exclusively within a single State.” $§ 5362(10)(B)(i)$.

${ }^{97}$ Engel, supra note 91, at 18.

${ }^{98}$ See generally Velotta, supra note 90.

${ }^{99} 386$ F. Supp. 3d 132 (D.N.H. 2019).

${ }^{100} I d$. at 136,140 .

${ }^{101} I d$. at 139 . The Michigan Bureau of State Lottery brief was also supported by the "Kentucky Lottery Corporation, the Tennessee Education Lottery Corporation, the Virginia Lottery, the Rhode Island Lottery, the Colorado State Lottery Division, the North Carolina Education Lottery, the State of Delaware, the State of Idaho, the State of Vermont, the State of Mississippi, the State of Alaska, and the District of Columbia." Id. at 139 n.2. The iDevelopment and Economic Association (iDEA) also filed an amicus brief in favor of the NHLC. Id. at $139 \mathrm{n} .3$. The Coalition to Stop Internet Gambling and the National Association of Convenience Stores filed amicus briefs in favor of the government. Id. 
judgment. ${ }^{102}$ In granting summary judgment in favor of NHLC, the court analyzed both NHLC's standing to bring the suit and the Wire Act's applicability to gambling unrelated to sports. ${ }^{103}$

\section{Standing}

The government alleged that the NHLC did not have standing to bring the action because there was no imminent threat of prosecution. ${ }^{104}$ The court rejected this argument finding that NHLC "easily satisfied" the imminence requirement. ${ }^{105}$ NHLC had "openly engaged for many years" in activities which the 2018 DOJ opinion would consider criminal under federal law. ${ }^{106}$ It further planned to continue the activities unless forced to stop for fear of prosecution. ${ }^{107}$ Additionally, the deputy attorney general had directed federal prosecutors to being enforcing the new opinion after a specified grace period, increasing NHLC's risk of prosecution. ${ }^{108}$

The government argued that an insufficient risk of prosecution failed to justify standing because the 2018 opinion did not "explicitly conclude that state agencies, state employees, and state vendors" would be subject to prosecution under the Wire Act. ${ }^{109}$ The court noted, however, that the 2011 opinion was issued in response to states' proposals to operate online lotteries and that the opinion never implied that states would be exempt from prosecution if the Wire Act applied to all forms of online gambling. ${ }^{110}$ Additionally, the 2018 opinion expressly noted that some states began selling online lottery tickets after the 2011 opinion, but that such "reliance interests" were insufficient to justify continued adherence to the 2011 opinion. ${ }^{111}$ Ultimately, the "temporary moratorium" on enforcement of the 2018 opinion and the "speculation" that that stay might become permanent was not enough to convince the court that NHLC lacked standing and the court allowed the action to proceed. ${ }^{112}$

\section{The Wire Act}

In analyzing whether the Wire Act applies to all forms of gambling and not just sports wagering, the court examined NHLC's proposed "series-qualifier rule" and the government's proposed "last-antecedent rule." Finding neither to be fully convincing, the court agreed with the 2011 opinion that the Act "can be read either way." "The court thus found the plain language of the Act to be ambiguous and turned to the "significant contextual evidence that calls the [2018 opinion] into question." 115

The court first examined the "context, structure, and coherence" of section 1084, guided by the rule that "[s]tatutes should be interpreted 'as a symmetrical and coherent regulatory scheme.""116 The court agreed with the 2011 opinion in finding no discernible reason why Congress would write the Act's first clause to prohibit the transmission of all bets or wagers but bar only information assisting in the placement of bets or wagers that concern sporting events. ${ }^{117}$ The court found an "even more serious coherence problem" with the Act's second clause. ${ }^{118}$ The second clause bars transmissions, which would enable payment for information that facilitates all types of gambling, where the first-class prohibits only the transmissions of sports-related information. ${ }^{119}$ Under the 2018 opinion, the first clause would permit the transmission of information that facilitates non-sports-related gambling while the second clause would criminalize transmissions that enable a person to receive payment for those same transmissions. ${ }^{120}$ The court found no reason for a "rational legislator" to draft a statute in such a way, concluding that it

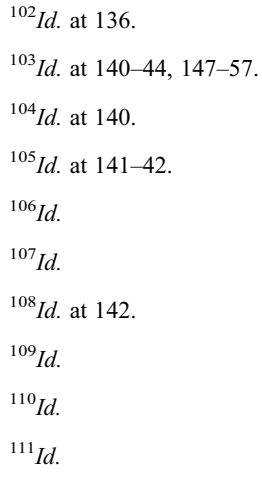

\footnotetext{
${ }^{112} I d$. at 143 .

${ }^{113}$ Id. at $148-51$.

${ }^{114} I d$. at 150 .

${ }^{115} I d$. at 152 .

${ }^{116} I d$. (internal citations omitted).

${ }^{117} I d$. at 152 .

${ }^{118} I d$.

${ }^{119} I d$.

${ }^{120} I d$.
} 
would be "bizarre to authorize an activity but prohibit getting paid for doing it." 121

The court bolstered its contextual analysis by looking to the Paraphernalia Act, which Congress passed on the same day as the Wire Act. ${ }^{122}$ The Paraphernalia Act prohibits transporting paraphernalia in interstate commerce, which is used in gambling activities, including bookmaking, sports wagering, and lotterystyle games. ${ }^{123}$ While the Paraphernalia Act lists lottery-style games such as "numbers, policy, [and] bolita," "124 the Wire Act contains no reference to such games. The court found this omission to be a "strong contextual signal concerning the Wire Act's scope."125 In other words, if Congress wished the Wire Act to apply to non-sports-related gambling activities "it knew how to say so." 126

The court next turned to the Wire Act's legislative history. ${ }^{127}$ While it is undisputed that the original draft of the bill was limited to sports gambling, the government pointed to an exchange between Senator Kefauver and then-Assistant Attorney General Herbert Miller to argue that the bill was amended to expand the scope to all forms of gambling. ${ }^{128}$ Senator Kefauver suggested three changes to the bill's draft including that the bill cover all forms of gambling. ${ }^{129}$ According to the government, the deletion of the commas surrounding the phrase "or information assisting in the placing of bets or wagers," 130 was "an efficient way" to expand the bill's scope. ${ }^{131}$ The court found this argument to be "too speculative to carry any weight."132 To the contrary, the redlined version of the bill's draft mistakenly reported that the comma following the phrase was never a part of the bill, indicating that its removal was uninten- tional. ${ }^{133}$ Further, in reporting the amendment, the Senate Judiciary Committee never mentioned an intention to expand the scope of the Act beyond sports gambling. ${ }^{134}$ The court concluded that the Act's legislative history also supported the 2011 DOJ opinion as a the better reading of the Wire Act. ${ }^{135}$ The appealate court decision used similar logic in upholding the decision. It noted:

The legislative history contains strong indications that Congress did indeed train its efforts solely on sports gambling. The statute as originally presented to Congress plainly aimed only at sports gambling. The language then contained only one clause, and it used commas to clearly indicate its focus on sports gambling. ${ }^{136}$

\section{Remedy}

The court granted NHLC declaratory relief and set aside the 2018 opinion. ${ }^{137}$ The parties, however, disagreed over the scope that the relief should have. ${ }^{138}$ The court agreed with the government that the remedy should not be universal, but should be limited to the parties of the case. ${ }^{139}$ While declining to give the judgment the broader scope which NHLC sought, the court did note that the judgment would "clearly" bind parties beyond the geographic jurisdiction of the District of New Hampshire. ${ }^{140}$ NeoPollard's iLottery system was being used in both New Hampshire and Michigan. ${ }^{141}$ NHLC has servers located in Vermont and Ohio. ${ }^{142}$ New Hampshire sells multijurisdictional games as a member of a compact with Maine and Vermont, sells Powerball and Mega Millions as part of the Multi-State Lottery Association, and takes

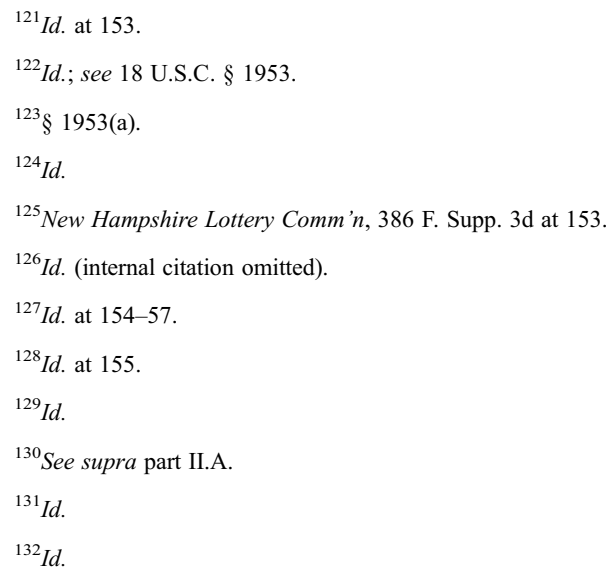

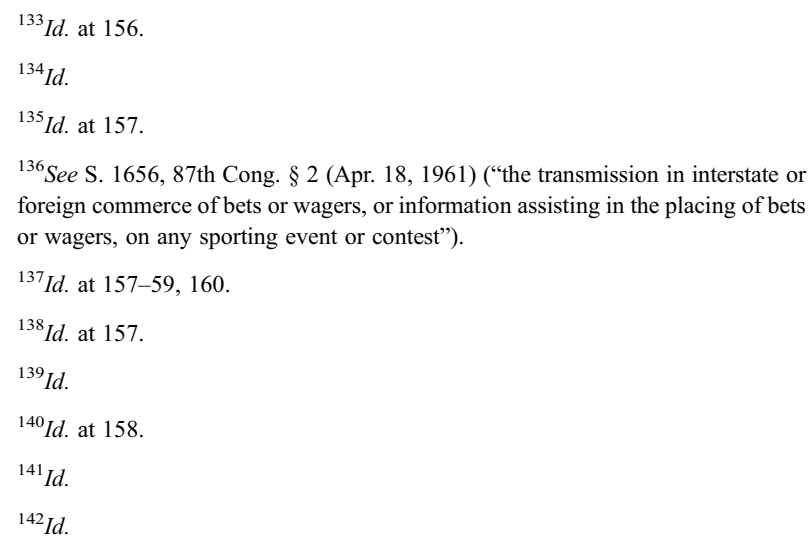


part in a consortium of 25 states and the District of Columbia that sells Lucky for Life. ${ }^{143}$ The court's judgment thus bound the government "vis-à-vis NeoPollard and the Lottery Commission everywhere the plaintiffs operate or would be otherwise subject to prosecution."144

The appealate court agreed with the district court and the Fifth Circuit in In Re MasterCard. It concluded:

The government's reading of the statute, however, would most certainly create an odd and unharmonious piece of criminal legislation. Neither common sense nor the legislative history suggests that Congress likely intended such a result. Like the Fifth Circuit, and the district court in this case, we therefore hold that the prohibitions of section 1084(a) apply only to the interstate transmission of wire communications related to any "sporting event or contest.

The government can seek a rehearing or appeal to the Supreme Court through a writ of certiorari. Still, with a change of administration, the government may abandon the case. The 2019 OLC opinion reversing the 2011 OLC opinion came under the Trump administration. Some saw the Trump administration's decision to reverse the 2011 OLC opinion adopted under President Obama as politically motivated as the change coincided with a vigorous campaign by a major campaign supporter who wanted to end internet gaming in the United States. ${ }^{145}$

\section{CHANGING STATE POLICIES TOWARD GAMBLING AND THE ROLE OF THE FEDERAL GOVERNMENT}

John F. Kennedy famously said, "[c]hange is the law of life. And those who look only to the past or present are certain to miss the future." 146 Sound public policy commands that Congress create new laws that take into consideration both contemporary mores and technology. That we must debate the legislative intent of the 1961 Wire Act to determine what is proper policy in the present is untenable. The internet has become the fabric of American life and commerce. Gambling policy and regulation have historically resided with policymakers at the state level. ${ }^{147}$ Despite the existing laws and the mandate of federal laws to assist the states, the federal government has significantly reduced its investigation and prosecution of gambling offenses. ${ }^{148}$ Prohibition without enforcement is a bad public policy.

This section argues that better public policy is to: (1) allow states to determine whether persons within its borders should be allowed to gamble online and to adopt regulations that meet government public policy; (2) leave the regulation of the wagering to the states where they can craft laws and regulations customized to meet their specific goals and circumstance; and (3) modernize and simplify federal law to give the federal government a clear mandate and authority to go after persons who operate outside of the state authorized and controlled environments.

Research suggests that Americans view gambling and the gaming industry more favorably than ever before. Eighty-eight percent of Americans consider gambling to be an acceptable form of entertainment. ${ }^{149}$ An all-time high 49 percent of Americans view the casino industry favorably and 57 percent of Americans believe casinos have a positive impact on the local economies in which they are located. ${ }^{150}$ This landscape represents a drastic evolution from the one that existed in 1961 when the Wire Act was passed. ${ }^{151}$ An even more radical change is how the

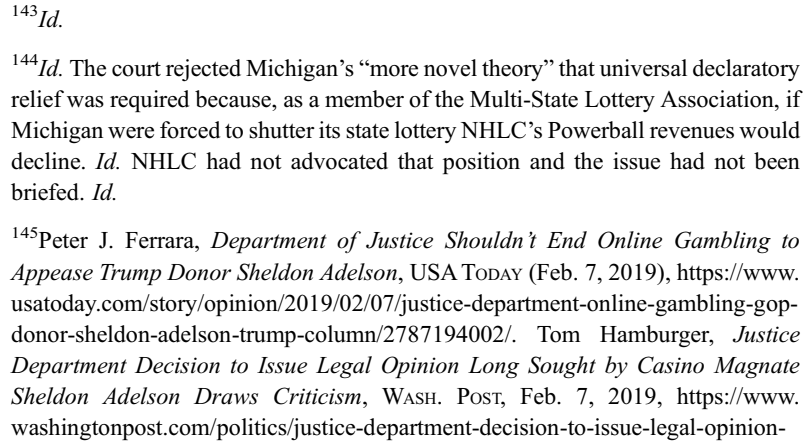

${ }^{144} I d$. The court rejected Michigan's "more novel theory" that universal declaratory relief was required because, as a member of the Multi-State Lottery Association, if Michigan were forced to shutter its state lottery NHLC's Powerball revenues would decline. Id. NHLC had not advocated that position and the issue had not been briefed. Id.

${ }^{145}$ Peter J. Ferrara, Department of Justice Shouldn't End Online Gambling to Appease Trump Donor Sheldon Adelson, USA TodAY (Feb. 7, 2019), https://www. usatoday.com/story/opinion/2019/02/07/justice-department-online-gambling-gopdonor-sheldon-adelson-trump-column/2787194002/. Tom Hamburger, Justice Department Decision to Issue Legal Opinion Long Sought by Casino Magnate Sheldon Adelson Draws Criticism, WASH. Post, Feb. 7, 2019, https://www. washingtonpost.com/politics/justice-department-decision-to-issue-legal-opinion-

long-sought-by-casino-magnate-sheldon-adelson-draws-criticism/2019/02/07/ fb705da6-2ae8-11e9-b011-d8500644dc98_story.html?noredirect $=$ on

${ }^{146}$ President John F. Kennedy, Address in the Assembly Hall at the Paulskirche in Frankfurt (June 25, 1963).

${ }^{147}$ See infra Part III.A.

${ }^{148}$ See infra notes $162-66$ and accompanying text.

${ }^{149}$ Press Release, American Gaming Association, New Research Reveals 90 Percent of Casino Visitors Practice Responsible Gaming (Feb. 13, 2019).

${ }^{150}$ Press Release, American Gaming Association, New Report Reveals Americans View Casino Industry More Favorably Than Ever (Oct. 15, 2019).

${ }^{151}$ See supra notes $20-29$ and accompanying text. 
internet has been incorporated into nearly every aspect of American life.

Since 2000, the percentage of American adults who use the internet has increased from 52 percent to 90 percent. ${ }^{152}$ While income and age can impact the extent to which some people use the internet, for many internet usage is "near ubiquitous." ${ }^{\text {"153 }}$ Nearly three-quarters of Americans have broadband internet at home, and at least some of those who do not use smartphones to access the internet at home. ${ }^{154}$ A significant 81 percent of Americans have access to the internet wherever they go through smartphone ownership. ${ }^{155}$ The internet has changed the way Americans connect with friends and family, pay bills, work, and entertain themselves. It has also impacted how Americans gamble.

Almost all states have some form of gambling, ${ }^{156}$ and internet gaming is beginning to proliferate sports wagering particularly. Since 2019, 17 states have authorized sports betting in one of the most rapid expansions of a form of gambling in U.S. history. ${ }^{157}$ Of these, all but three have authorized mobile sports wagering. ${ }^{158}$ This has a sound economic basis as 81 percent of annual sports wagering revenue in New Jersey, as an example, came from mobile wagering in 2019. ${ }^{159}$ Even more states are considering legislation that would permit sports betting, and the number of states legalizing and regulating sports betting will inevitably increase in 2020 and beyond. ${ }^{160}$ Additionally, 11 states offer lottery products online, and six have or have authorized online casino games. ${ }^{161}$

${ }^{152}$ Pew Research Center, Internet/Broadband Fact Sheet, Pew Research Center (June 12, 2019), https://www.pewresearch.org/internet/fact-sheet/internetbroadband/.

${ }^{153} I d$.

${ }^{154} I$.

${ }^{155}$ Pew Research Center, Mobile Fact Sheet, Pew Research Center (June 12, 2019), https://www.pewresearch.org/internet/fact-sheet/mobile/.

${ }^{156}$ American Gaming Association, supra, note 61, at 10-13.

${ }^{157}$ As of May 1, 2020, the following states have legalized sports betting and that activity is being conducted in the state: Arkansas, Colorado, Delaware, Illinois, Indiana, Iowa, Nevada, New Hampshire, New Jersey, New York, Michigan, Mississippi, Montana, Oregon, Pennsylvania, Rhode Island, and West Virginia. Legislative Tracker: Sports Betting, Legal Sports ReP., https://www. legalsportsreport.com/sportsbetting-bill-tracker/ (last updated Apr. 7, 2020). New Mexico also offers sports betting at some of its tribal casinos through a gaming compact. $I d$.

${ }^{158}$ Ryan Butler, Where is Sports Betting Legal? Projections for All 50 States, ACTION NETWORK (Feb. 4, 2021), https://www.actionnetwork.com/news/ legal-sports-betting-united-states-projections.
Federal enforcement of gambling laws has been sporadic and inconsistent. The year after the UIGEA was passed, the House Committee on the Judiciary held a hearing to discuss how to establish consistent enforcement policies as related to internet gambling. ${ }^{162}$ Chairman John Conyers Jr. noted that gambling enforcement is "selectively picked and chosen" and questioned why the Wire Act is not adequately enforced. ${ }^{163}$ Representative Shelley Berkley highlighted the complex environment for Americans who wanted to wager online created by "[a] combination of outdated laws, selective enforcement by the Justice Department, and an intentional lack of clarity by Congress." ${ }^{164}$ More recently, with the advent of daily fantasy sports, commentators have questioned the reasoning behind passing new gambling laws when law enforcement officials largely ignore existing gambling laws. ${ }^{165}$ A significant concern with sporadic enforcement is that it penalizes those who seek to adhere to the law while rewarding those who are willing to push the law's limits. ${ }^{166}$

Instead of broad but inconsistently enforced federal gambling laws, each state should determine whether its citizens can gamble, and craft regulations that meet state policies toward regulated gaming and responsible gambling. Additionally, federal law enforcement should receive a clear mandate and the authority needed to prosecute those who operate gambling enterprises outside of the state-controlled environment.

\footnotetext{
${ }^{159}$ American Gaming Association, supra note 61, at 7.

${ }^{160}$ As of May 1, 2020, North Carolina, and Tennessee have legalized sports betting and are pending launch. Id. Alabama, Alaska, Arizona, California, Connecticut, Florida, Georgia, Hawaii, Kansas, Kentucky, Louisiana, Maine, Maryland, Massachusetts, Minnesota, Missouri, Nebraska, North Dakota, Ohio, South Carolina, South Dakota, Texas, Vermont, Virginia, Washington, and Wyoming have all at least introduced bills that would legalize sports betting. See id.

${ }^{161}$ American Gaming Association, supra note 61, at 13-14

${ }^{162}$ Establishing Consistent Enforcement Policies in the Context of Online Wagers, Hearing Before the Comm. on the Judiciary, 110 Cong. (2007).

${ }^{163}$ Id. at 1-2 (Statement of John Conyers Jr.).

${ }^{164} I d$. at 3 (Statement of Shelley Berkley).

${ }^{165}$ See, e.g., Marc Edelman and John Holden, Commentary: Why Create New Gambling Laws When We Don't Enforce Our Existing Ones?, Chicago Tribune (Jul. 29, 2019), https://www.chicagotribune.com/opinion/commentary/ct-opiniongambling-casinos-sports-betting-laws-20190729-347fzxzfpfdztkwhqxh347lypmstory.html.

${ }^{166} I d$.
} 


\section{A. The states should determine the legality of gambling}

Gambling policy and regulation have historically resided with policymakers at the state level. As early as 1638, Massachusetts enacted an anti-gambling statute. ${ }^{167}$ Since then, many states have revised their gambling statutes multiple times, vacillating between prohibition and regulation. ${ }^{168}$ From Nevada's passage of the "Wide Open Gambling Bill" in 1931 , the state remained the only one to have legalized gambling until 1964 when New Hampshire introduced its state lottery. ${ }^{169}$ Today, all states but two have some form of legalized gambling. ${ }^{170}$

States widely differ in their approach to gambling legislation. Some states, like Pennsylvania and Iowa, have espoused gambling in its many forms. ${ }^{171}$ Others, like Utah and Hawaii, have maintained a policy of prohibition. ${ }^{172}$ Both positions can be supported as matters of public policy. Critics of legalized gambling cite concerns about organized crime, morality, and gambling addiction. ${ }^{173}$ Proponents can point to the economic benefits of commercial gambling ${ }^{174}$ and, in the case of state lotteries, the fact that revenue goes into funding for public programs like education. ${ }^{175}$ Because reasonable minds can differ on such issues, states' rights should govern an issue as polarizing as gambling legislation.

The founders understood the diversity of opinions on domestic issues among the original 13 states. ${ }^{176}$ They addressed this concern mainly by reserving policymaking authority on such matters to the states via the Tenth Amendment. ${ }^{177}$ While the country is staggeringly larger today and exponentially more diverse, the logic behind federalism remains the same. ${ }^{178}$ Keeping policymaking on domestic issues with the states ensures that the preferences of state citizens are reflected in the law. ${ }^{179}$

\section{B. Gambling regulations should be tailored to each state's needs and circumstance}

The government has legitimate public policy reasons for wanting to regulate gambling, including that the games are honest, persons are secure in their deposits and earnings, and to minimize problem gambling and promote responsible gambling. While the Constitution's Supremacy Clause provides that federal law takes precedence over state law, ${ }^{180}$ the clause does not apply where the federal government has exceeded the constitutional limitations on federal power. ${ }^{181}$ As discussed above, it is appropriate to leave domestic issues to state policymakers. ${ }^{182}$ Doing so ensures that gambling regulations are tailored to each state's individual needs and circumstances.

The Supreme Court recently addressed this issue, in the context of sports betting, in Murphy v. National Collegiate Athletic Association. ${ }^{183}$ There, the Court examined whether a federal prohibition on sports betting, the Professional and Amateur Sports Protection Act (PASPA), was "compatible with the system of 'dual sovereignty' embodied in the Constitution." 184 PASPA was passed in the early 1990s mainly as a response to the legalization of other forms of gambling. ${ }^{185}$ The stated purpose of the bill was to protect the integrity of amateur and

\footnotetext{
${ }^{167}$ George G. Fenich, A Chronology of (Legal) Gaming in the U.S., 3 UNLV Gaming Research \& Rev. J. 65, 66 (1996).

${ }^{168} I d$. at $66-76$ (chronicling state gambling statutes throughout time).

${ }^{169} \mathrm{Id}$. at 70; see also supra, notes 59-60 and accompanying text.

${ }^{170}$ See American Gaming Association, supra note 61, at 12-13

${ }^{171} I d$.

${ }^{172} I d$.

${ }^{173}$ See e.g., Mike Roberts, The National Gambling Debate: Two Defining Issues, 18 WhitTIER L. Rev. 579, 590, 600 (1997).

${ }^{174}$ American Gaming Association, supra note 61, at 20.

${ }^{175}$ See e.g., Kathleen Ferraiolo, Is State Gambling Policy "Morality Policy?" Framing Debates Over State Lotteries, 41 Policy Studies J. 217, 235 (2013).

${ }^{176}$ Christopher Z. Mooney, The Decline of Federalism and the Rise of MoralityPolicy Conflict in the United States, 30 Publius: J. of Federalism 171, 178 (2000).

${ }^{177} I d$. See also U.S. Const. amend. X.
}

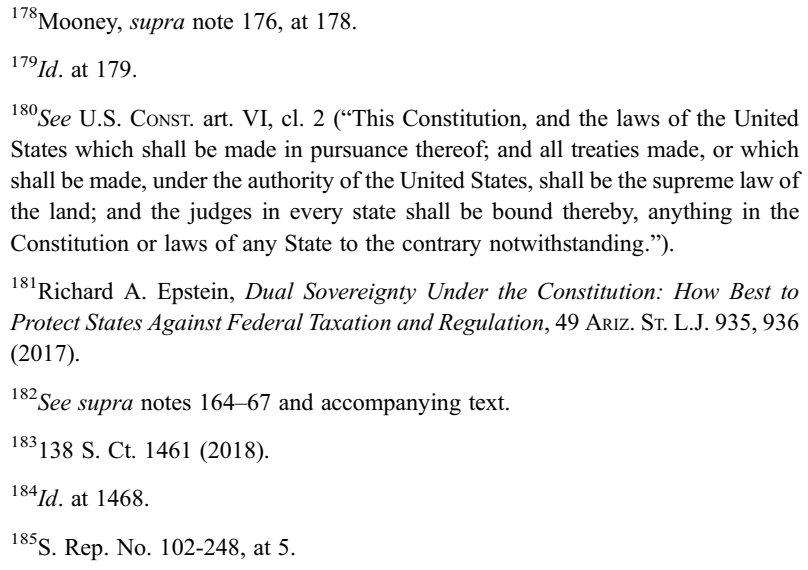

${ }^{181}$ Richard A. Epstein, Dual Sovereignty Under the Constitution: How Best to Protect States Against Federal Taxation and Regulation, 49 Ariz. ST. L.J. 935, 936 (2017)

${ }^{182}$ See supra notes $164-67$ and accompanying text.

${ }^{183} 138$ S. Ct. 1461 (2018).

${ }^{184} I d$. at 1468 .

${ }^{185}$ S. Rep. No. $102-248$, at 5 
professional sporting events. ${ }^{186}$ Despite DOJ opposition, the bill passed and was signed into law. ${ }^{187}$ PASPA made it unlawful for a state " to sponsor, operate, advertise, promote, license, or authorize by law or compact [...] a lottery, sweepstakes, or other betting, gambling, or wagering scheme based [...] on' competitive sporting events."188 After New Jerseyans voted, in 2011, to authorize sports gambling, state officials sought to enjoin PASPA, arguing, in part, that the statute unconstitutionally infringed on the state's sovereign authority to end its sports gambling ban. ${ }^{189}$

New Jersey invoked the "anticommandeering" doctrine established by the Court in New York v. United States $^{190}$ and Printz v. United States, ${ }^{191}$ arguing that PASPA restricted the state's lawmaking power by preventing it from repealing its sports gambling ban. ${ }^{192}$ New York concerned a provision of federal law requiring state executives or legislatures to take title to radioactive waste as instructed by Congress. ${ }^{193}$ The Court held that the provision was unconstitutional because "the Constitution does not empower Congress to subject state governments to this type of instruction." ${ }^{194}$ Five years later, in Printz, the Court invalidated a federal law requiring state and local law enforcement to perform background checks for handgun applications. ${ }^{195}$ The Court held that Congress does not have the authority to "command" state and local officials "to administer or enforce a federal regulatory program."

In Murphy, the Court outlined three reasons why adherence to the anticommandeering principle is essential. ${ }^{197}$ First, the doctrine serves as "one of the Constitution's structural protections of [individual] liberty." ${ }^{198}$ Second, the doctrine promotes political accountability by providing voters with someone to credit or blame for the results of a given regulation. ${ }^{199}$ And third, the doctrine "prevents Congress from shifting costs of regulation to the States."200 The Court then held that PASPA "unequivocally dictates what a state legislature may and may not do," and declared the statute unconstitutional under the anticommandeering doctrine. ${ }^{201}$

\section{Gambling regulation and federal law}

Federal public policy has always been to support the state governments in enforcing their public policies regarding gambling. In the case of Utah and Hawaii, this means to provide the national and international law enforcement to investigate and prosecute persons from outside these states from offering gambling to persons physically located in these states. In states which have embraced gaming, like Pennsylvania, the federal government assists these states to investigate and prosecute persons who provide or profit from gambling that offers gambling outside the state-authorized and controlled environment.

The legislative history of federal gambling statutes demonstrates congressional intent to aid local governments in enforcing gambling laws as opposed to preempting state law with federal law. During his campaign to pass the Wire Act, Attorney General Kennedy noted that "such crimes as gambling" had traditionally been handled by local authorities. ${ }^{202} \mathrm{He}$ further emphasized that his office "[did] not seek to preempt the field of enforcement or interfere in any way with the traditional responsibilities of local law enforcement. ${ }^{, 203}$ Instead, the Wire Act was to establish cooperation between federal and local law enforcement to eradicate multistate organized crime. ${ }^{204}$

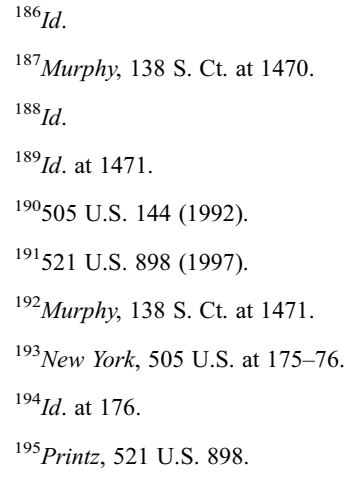

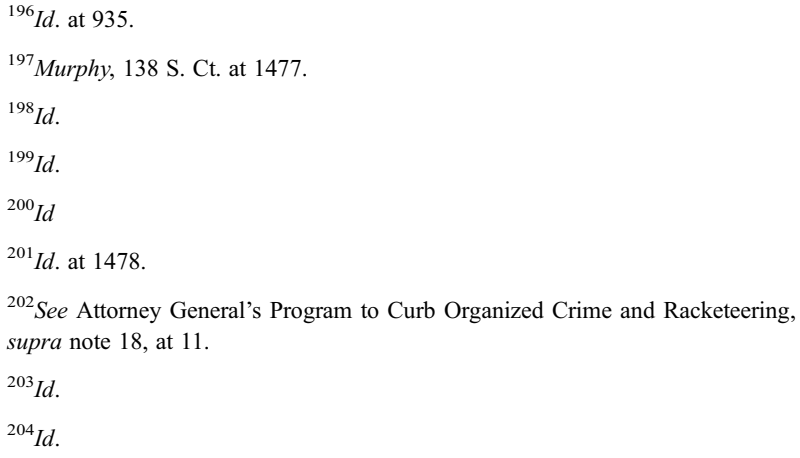


Similarly, in contemplating the Illegal Gambling Business Act of $1970,{ }^{205}$ Congress was concerned with exceeding federal jurisdiction. In its report, the Senate Committee on the Judiciary expressly noted that it was "not to bring all illegal gambling activity within the control of the Federal Government." 206 Rather, the Committee explained how the Commerce Clause gives Congress the right to regulate "a particular aspect of gambling operations" where they are of a specific size to affect interstate commerce. ${ }^{207}$ While the bill was aimed at permitting federal intervention where local law enforcement had become too corrupt to stop illegal activities, the report again states that "the enforcement of criminal laws against gambling and other illegal activities is generally the responsibility of the States and local governments in our Federal system."208

\section{A PROPOSAL FOR UPDATING THE WIRE ACT}

The overall objective of an updated Wire Act should restore the use of the Wire Act to assist states in protecting their legal gambling markets rather than undermining their legal markets. The state of regulated gaming has shifted from the 1960s when Nevada was a pariah state because it permitted casinos and sports wagering. States are fully embracing not only casinos and sports wagering but are increasingly receptive to online casino, sports, and lottery offerings. The states, however, have structural, resource, and jurisdictional limitations to their ability to police illegal operations that occur primarily in foreign jurisdictions. Because state regulation and taxation add additional cost to a regulated online offering, legal sites cannot effectively compete with offshore sites without effective policing of illegal casino sites, which are both a state and federal problem. As Robert Kennedy noted in 1961, these unlawful gambling sites can serve to support organized crime. Sports wagering is particularly worrisome because these markets lack the transparency that enables match fixers to compromise the integrity of the underlying sporting events. Moreover, illegal sites fail to provide fundamental assurances that protect the patrons from fraud, business failures, and irresponsible gambling behavior. Therefore, the primary focus of a revised Wire Act should be on federal criminal investigation and prosecution of illegal unregulated and untaxed casinos, bookmakers, and other gambling operations operating outside the United States that accept wagers from U.S. residents. The appendix contains the statutory framework that the Congress should consider in amending the Wire Act.

The updated Wire Act also should restore the rights of states to control purely intrastate gambling activities. As was recognized in the UIGEA, a significant step would be to define that intrastate means when both the sender and the recipient are physically in the same state. The statute should not be based on the facetious argument that the path of the data packets used to send internet communications should determine whether the matter is intrastate or interstate. When data packets are transmitted online, they may come from and go to points in the same state. Because the internet seeks to deliver the data as efficiently as possible, however, no guarantee exists that the transmission did not travel across state boundaries during its journey from a bettor to a sportsbook computer server, even when both are in the same state. ${ }^{209}$ Such a reading of the Wire Act makes an online intrastate betting market an impossibility. The baselessness of this argument is more easily understood when one recognizes that the original Wire Act was never intended to apply when a bookie and a patron used the telephones in the same state to communicate. The idea that merely updating the technology of the telephone system and creating the internet infrastructure should change federal policy is both incorrect and unwarranted.

As the purpose of the Wire Act is to assist the states, no barriers should be erected to cross state agreements with other states. These facilitate joint enforcement, shared liquidity and tax revenue, and allow sports businesses to engage in multi-jurisdictional risk management. These matters, along with cooperative agreements regarding data and intelligence

\footnotetext{
${ }^{205} 18$ U.S.C. $\S 1955$.

${ }^{206}$ S. Rep No. 91-617, at 73 (1969).

${ }^{207}$ Id. at 74

${ }^{208} I d$.
}

\footnotetext{
${ }^{209}$ See Pamela Fox, Internet Routing Protocol, Khan ACADEMy, https://www. khanacademy.org/computing/ap-computer-science-principles/the-internet/tcpfault-tolerant-transmission-protocol/a/internet-routing-protocol (last accessed Apr. 21, 2020)
} 
sharing, strengthen the regulated markets in each state and promote the state public policies underlying gambling activities.

The 1961 Wire Act prohibited the transmission of information assisting in the placing of a bet or wager. The purpose of this inclusion was to establish a crime where the bookie revealed the odds on the game, but the patron did not accept the wager, or where the book operator transmitted the odds to its agents that dealt directly with the patrons. With technology, the odds offered by all major bookmakers are available online. As a practical matter to establish that the bookmaker is accepting wagers from the U.S., law enforcement needs to create an account and make a wager from the U.S. The prosecutorial advantage of having the ability to prosecute the transmission of wagering information is insubstantial, but the uncertainty of the application of the statute is substantial. The transmission of information regarding sports wagering saturates all media, particularly since the introduction of the internet. Major publications and websites carry the current odds on major sporting events, and broadcasts often refer to such odds. Regulated books, however, face uncertainty if they provide their current odds to newspapers, websites, or other online outlets. It results in untenable situations where licensed and regulated sports businesses cannot widely share their betting information, but illegal offshore bookmakers have no barriers. Attempting to criminalize the transmission of information is also constitutionally problematic and poor use of government resources.

The updated Wire Act should empower the Federal Bureau of Investigation (FBI) with the financial resources and additional tools to investigate and deter illegal offshore operators. Allocating an appropriate amount of money to the prosecution of illegal online wagering would cure financial resources. The draft suggests $\$ 10$ million per year. The second is to add powers to quickly interrupt the flow of money between an offshore operator and its U.S. patrons. A substantial amount of these funds flow through branded credit cards. To open these accounts for access to U.S. customers, the illegal sites often misrepresent the nature of their business. If the FBI had a vehicle to quickly notify the credit card companies or merchant banks of the illicit use of the credit cards and stop their use until and unless the site seeks a hearing, it would hamper the ability of the sites to accept U.S. wagers. Moreover, the provision would apply to other transfers, including bank transfers.

Other changes proposed include shortening "bets or wagers" to only wagers and providing a commonly used definition with significant precedent, and adding a definition of an event to assure that the definitions are consistent with the ability to make in-game wagering. The definition makes clear that the underlying predicate state offense must be a criminal offense to avoid application to regulatory violations by licensed operators. The updated version also would expand the definition of foreign commerce to cover any attempts to conduct illegal wagering from outside the United States, even from international waters.

\section{APPENDIX: RESTORING THE WIRE ACT TO PROTECT STATES' RIGHTS}

(a) A person engaged in the business of wagering that knowingly uses a wire communication facility for the transmission in interstate or foreign commerce of an unlawful wager shall be fined as provided under 18 U.S. Code $\S 3571$ or imprisoned not more than two years, or both.

(b) When any Federal or state law enforcement agency acting within its jurisdiction notifies a financial transaction provider, that it is furnishing services being used or will be used by a person violating this section, the financial transaction provider shall discontinue or refuse service, after reasonable notice. The financial transaction provider shall not be subject to damages, penalty or forfeiture, civil or criminal, for complying with such notice. Nothing in this section shall prejudice the right of any person affected thereby to secure an appropriate determination, as provided by law, in a Federal court that such service should not be discontinued or removed or should be restored.

(c) The sum of $\$ 10,000,000$ is authorized to be appropriated to the Director of the Federal Bureau of Investigation for each fiscal year 
2020 through 2023 to investigate violations of this section.

(d) Nothing contained in this section shall create immunity from criminal prosecution under any laws of any State.

(e) As used in this section,

The term "Event" means any identifiable outcome can occur.

The term "Interstate commerce" includes commerce between one State, Territory, Possession, or the District of Columbia and another State, Territory, Possession, or the District of Columbia, but does not include when the bet or wager is initiated and received or otherwise made exclusively within a single State. The intermediate routing of electronic data shall not determine the location or locations in which a bet or wager is initiated, received, or otherwise made.

The term "Financial transaction provider" means a creditor, credit card issuer, financial institution, operator of a terminal at which an electronic fund transfer may be initiated, money transmitting business, or international, national, regional, or local payment network used to effect a credit transaction, electronic fund transfer, stored value product transaction, or money transmitting service, or other participants in a payment system.
The term "Foreign commerce," as used in this title, includes commerce between one State, Territory, Possession, or the District of Columbia and another State, Territory, Possession, or the District of Columbia, and a foreign country or a person located in International waters.

The term "State" means a State of the United States, the District of Columbia, the Commonwealth of Puerto Rico, or a commonwealth, territory, or possession of the United States.

The term "Unlawful wager" means a wager that if placed or accepted is a criminal offense under a State law where the wager is either initiated or received.

The term "Uses a wire communication facility for the transmission in interstate or foreign commerce" means any transmission over the Internet carried interstate or in foreign commerce;

The term "Wager" means when a person stakes or risks something of value upon a future contingent event not within the control of that person upon an agreement that the person or someone else will receive something of value in the event of a certain outcome.

The term "Wire communication" has the meaning given the term in section 3 of the Communications Act of 1934 (47 U.S.C. $\S 153$ ). 